\title{
Pengaruh Orientasi Etis, Gender, Dan Pengetahuan Kode Etik Akuntan Terhadap Persepsi Mahasiswa Akuntansi Mengenai Perilaku Tidak Etis Akuntan
}

\author{
Ketut Ria Mutiarasari ${ }^{1}$, I Putu Julianto ${ }^{2}$ \\ 1,2 Program Studi S1Akuntansi, Universitas Pendidikan Ganesha \\ Singaraja, Indonesia \\ e-mail: ${ }^{1}$ | mutiarasariria8@gmail.com, ${ }^{2} \mid$ putujulianto@undiksha.ac.id
}

\begin{abstract}
Abstrak
Tujuan penelitian ini untuk mengetahui pengaruh Idealisme, Relativisme, Gender, dan Pengetahuan Kode Etik Akuntan terhadap Persepsi Mahasiswa Akuntansi mengenai Perilaku Tidak Etis Akuntan. Penelitian ini menggunakan pendekatan kuantitatif dengan data primer yang diperoleh dari kuesioner serta diukur menggunakan skala likert. Populasi dari penelitian ini, yaitu mahasiswa akuntansi universitas di Bali sebanyak 1.115 orang. Teknik pengambilan sampel menggunakan convenience sampling dengan kriteria sampel mahasiswa akuntansi yang pernah magang atau bekerja di Kantor Akuntan Publik atau di Kantor Jasa Akuntan dan mahasiswa yang telah menempuh mata ajar program Pendidikan Profesi Akuntansi. Penentuan jumlah minimal sampel menggunakan tabel Isaac dan Michael dengan tingkat signifikansi 5\%, diperoleh jumlah sampel sebanyak 265 orang. Teknik analisis data menggunakan analisis regresi linier berganda dengan menggunakan SPSS 22.0. Hasil penelitian menunjukan bahwa idealisme dan pengetahuan kode etik akuntan memiliki pengaruh negatif terhadap persepsi mahasiswa akuntansi mengenai perilaku tidak etis akuntan, sedangkan relativisme memiliki pengaruh positif terhadap persepsi mahasiswa akuntansi mengenai perilaku tidak etis akuntan dan mahasiswa akuntansi laki-laki terbukti lebih memberikan persepsi yang mendukung perilaku tidak etis akuntan dibandingkan dengan mahasiswa perempuan.
\end{abstract}

Kata Kunci : Idealisme, Relativisme, Gender, Pengetahuan Kode Etik Akuntan, Persepsi Mahasiswa, Perilaku Tidak Etis Akuntan

This study aims to determine the effect of Idealism, Relativism, Gender, and Knowlegde of Ethic Accounting Code of Accounting Students' Perseption on Unethical Accounting Behavior. This study used quantitative approach with primary data obtained from questionnaires and measured using a Likert Scale. The population of this study were accounting students at five universities in Bali in total 1,115 people. The sampling technique used convenience sampling with a sample criteria of accounting students who had been interned or worked at a Public Accounting Firm or at an Accountant Services Office, and accounting student who had taken courses in the Accounting Professional Education program. Determination of the minimum number of samples used the Isaac and Michael tables with a significance level of 5\%, obtained a total sample of 265 people. Data analysis technicque used multiple linear regression analysis by using SPSS 22.0 for Windows. The result showed that idealism and knowledge of ethic accountant code had a negative influence on accounting student' perseptions of accountant's unethical behavior, while relativism had positive influence on accounting students'perseptions of accountant's unethical behavior and male accounting students' perception was proven more support unethical accountant's behavior rather than female accounting students.

Keywords : Idealism, Relativism, Gender, Kowledge of Accountant Ethics, Student Perseption, Accountant Unethical Behavior

\section{Pendahuluan}

Perilaku etis profesi akuntan saat ini menjadi pembicaraan yang hangat di lingkungan masyarakat. Profesi akuntan dalam menjalankan pekerjaannya harus memiliki rasa 
mendukung tinggi moral dan etika (Lubis, 2010). Kasus-kasus yang terjadi di sektor swasta maupun pemerintahan sebagian besar merupakan skandal keuangan. Kasus pada skandal keuangan yang terjadi tidak terlepas dari profesi akuntan. Skandal keuangan ini dapat berdampak kepada beberapa pihak, baik pihak yang sudah berprofesi maupun yang sedang mempersiapkan diri untuk menjadi profesi akuntan.

Skandal akuntansi yang pertama dilakukan oleh akuntan dari PT. Sunprima Nusantara Pembiayaan (SNP). Pada laporan keuangan perusahaan periode 2012-2016, dua akuntan publik telah salah melakukan audit laporan keuangan perusahaan. Akuntan publik tersebut bernama Marlinna dan Merliyana Syamsul yang tidak mengikuti standar etika yang berlaku. Kedua akuntan publik belum sepenuhnya mengendalikan sistem informasi data nasabah serta keakuratan jurnal piutang pembiayaan dan tidak mengikuti prosedur mengenai pendektesian fraud. Ini akan berdampak pada skeptisisme profesi akuntan.

Skandal akuntansi juga dialami oleh PT. Kimia Farma, Tbk. Perseroan Terbatas telah memanipulasi laporan keuangan perusahaan. Perusahaan menaikkan laba bersih pada laporan keuangan 2001. Perusahaan berhasil mendapatkan laba berjumlah $R p$ 132.000.000.000. Setelah auditor eksternal melakukan pengauditan kembali pada 3 Oktober 2002, auditor menemukan kesalahan pada laporan keuangan, yaitu keuntungan yang

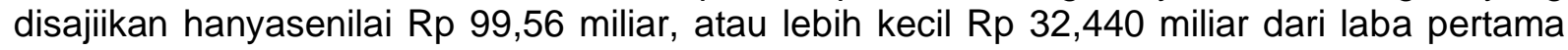
yang perusahaan laporkan. Kekeliruan ini terkait dengan persediaan yang digelembungkan, serta kesalahan penyajian penjualan adalah melakukan penjualan perusahaan berganda. KAP Hans, Tuanakota, dan Mustofa (HTM), diduga terlibat pada tindakan penggelembungan. Badan Pemeriksa Keuangan Pemerintah memeriksa kertas kerjayang diibuat oleh Kantor Akuntan Publik serta menegaskan auditor tidak mengikuti standar yang berlaku.

Skandal-skandal bisa akuntansi berdampak buruk untuk profesi akuntan, respon, dan persepsi dari mahasiswa akuntansi sebagai calon seorang akuntan. Persepsi mahasiswa tentang pelanggaran etika akan mempengaruhinya menentukan karirnya. Orientasi etis adalah aspek yang dapat memberikan pengaruh terhadap persepsi mahasiswa tentang tindakan tidak etis. Bagian-bagian orientasi etis, yaitu idealisme dan relativisme. Idealisme dan relativisme merupakandua aspek filosofi moral dari setiap orang. Seseorang yang idealis akan bertindak tegas jika ada suatu kondisi yang memberikan dampak buruk bagi orang lain serta memegang kuat prinsip dan moral yang bersifat universal. Hasil penelitian Mardawati dan Aisyah (2014), menyebutkan bahwa idealisme berpengaruh pengaruh negatif terhadap persepsi mahasiswa tentang perilakutidak ettis akuntan, sedangkan berdasarkan penelitian Sakinah (2017), menyebutkan idealisme berngaruh positif terhadap persepsi mahasiswa tentang perilakutidak etis akuntan. Berdasarkan hal tersebut, dapat dirumuskan hipotesis pertama $\left(\mathrm{H}_{1}\right)$ dari penelitian ini yaitu :

$\mathrm{H}_{1}$ : Idealisme berpengaruh negatif terhadap persepsi mahasiswa akuntansi mengenai perilaku tidak etis akuntan.

Seseorang yang melakukan skandal akuntansi lebih memiliki sikap relativisme. Relativisme adalah tindakan tidak menerima prinsip serta peraturan moral secara global serta memiliki rasa akan perilaku moral itu akibat dari keadaan pribadi serta kondisi yang dilibatkan. Seseorang yang memiliki sifat relativis tidak menjunjung dasar-dasar moral yang telah ada dan melihat kondisi sebelum bertindak untuk menanggapi kejadian pelanggaran etis. Hasil penelitian dari Yuliani (2019), menyebutkan bahwa relativisme memillki pengaruh yang positif terhadap persepsi mahasiswa tentang perilaku tidak etis akuntan, sedangkan hasil penelitian dari Sakinah (2017), menyebutkan bahwa relativisme berpengaruh negatif pada persepsi mahasiswa tentang perilaku tidaketis akuntan. Berdasarkan hasill penelitian tersebut, dapat dirumuskan hipotesiskedua $\left(\mathrm{H}_{2}\right)$ dari penelitian ini yaitu:

$\mathrm{H}_{2}$ : Relativisme berpengaruh positif terhadap persepsi mahasiswa akuntansi mengenai perilaku tidak etis akuntan.

Persepsi yang berbeda dari tiap individu bukan hanya diakibatkan oleh lingkungan, namun juga terjadi disebabkan oleh perbedaan gender. Menurut hasil penelitian dari 
Sankaran dan Bui (2003), persepsi yang tidak sama terlihat antara pria dan wanita. Perbedaan persepsi antara perempuan dengan laki-laki memberikan pengaruh terhadap pengambilan suatu keputusan. Hal ini disebabkan karena perempuan lebih memiliki sifat sensitif dari pada laki-laki mengenai isu etika untuk pengambilan keputusan, maka jika ada pelanggaran etika perempuan akan lebih bersikap tegas. Suatu penilaian akan dilakukan secara berbedaa antara laki-laki dengan perempuan terkait dengan situasi yang tidak beretika. Hasil penelitian dari Akbar (2009), menyebutkan mahasiswa priia dan wanita mempunyai persepsi yang berbeda terkait persepsi mahasiswa tentang perilaku tidak etis akuntan, sedangkan menurut penelitian Yuliani (2019), mahasiswa laki-laki dengan perempuan mempunyai persepsi yangsama ke persepsi mahasiswa tentang perilaku tidak etisakuntan. Berdasarkan hal tersebut, dapat dirumuskan hipotesis ketiga $\left(\mathrm{H}_{3}\right)$ pada penelitian ini yaitu :

$\mathrm{H}_{3}$ : Gender berpengaruh terhadap persepsi mahasiswa akuntansi mengenai perilaku tidak etis akuntan.

Pengetahuan kode etik akuntan juga dapat mempengaruhi persepsi mahasiswa tentang tindakan tidak etis. Suatu informasi diperoleh dari pengetahuan dan memberikan manfaat untuk memecahkan suatu masalah yang terjadi. Kesadaran mahasiswa yang tidak memadai akan perilaku etis yang harus diterapkan akuntan disebabkan dari kurangnya pengetahuan mengenai skandal akuntansi yang terjadi (Praditya, 2019). Penegakan kode etik akuntan harus diawali dengan memahami serta menghayanti perilaku etis dengan kesadaran yang tinggi sejak berada di bangku kuliah. Pemahaman serta penghayatan ini dapat mengurangi perbagai perilaku yang melanggar etika. Menurut hasil penelitian Sakinah (2017), menyebutkan bahwa pengetahuan kode etik profesi akuntan memiliki pngaruh positif pada persepsi mahasswa tentang perilaku tidak etisakuntan, sedangkan menurut hasil penelitian Mardawati dan Aisyah (2014), meghasilkan pngetahuan etika profesi berpengaruh negatif pada persepsi mahasiswa mengenai perilaku tidak etis akuntan. Berdasarkanhal tersebut, rumusan hipotesis keempat $\left(\mathrm{H}_{4}\right)$ dari penelitian ini yaitu :

$\mathrm{H}_{4}$ :Pengetahuan Kode Etik Akuntan berpengaruh negatif terhadap persepsi mahasiswa akuntansi mengenai perilaku tidak etis akuntan.

\section{Metode}

Penelitian ini menggunakan pendekatan kuantitatif dengan data primer yang diperoleh dari kuesioner serta diukur menggunakan skala likert. Kuesioner didistribusikan secara langsung kepada responden melalui google form. Populasi penelitian, yaitu mahasiswa akuntansi Politeknik Negeri Bali, Politeknik Negeri Denpasar, Universitas Udayana, Universitas Pendidikan Ganesha dan Akademi Akuntansi Denpasar sebanyak 1.115 orang. Teknik pengambilan sampel memakai convenience samplingdengan menentukan jumlah minimal sampel memakai tabel Isaac dan Michael tingkat signifikansi 5\%, diperoleh total sampel, yaitu 265 orang. Adapun kriteria sampel, diantaranya mahasiswa akuntansi yang pernah magang ataupun bekerja di Kantor Akuntan Publik atau Kantor Jasa Akuntan dan mahasiswa yang sudah menempuh mataajar program Pendidikan Profesi Akuntansi. Penelitian ini menggunakan pendekatan kuantitatif dengan data primer yang dperoleh dari kuesioner serta diukur dengan mnggunakan skala likert. Kuesioner didistribusikan secara langsung kepada responden melalui google form.

Teknik analisis data pada penelitian ini, yaitu analisis statiistik deskriptif. Adapun uji kualitas data penelitian ini, diantaranya ujivaliditas serta uji reliabilitas, sedangkan uji asumsi klasik, yaitu uji normalitas, uji multikolinieritas, dan uji heterokesdatisitas. Uji hipotesis meggunakan uji regresi linier berganda, uji parsial (uji t) dan uji independent $t$ test, dan uji koefisien determinasi (Adjustd- $R^{2}$ ).

\section{Hasil Dan Pembahasan}

Adapun jumlah kuesioner yang disebar adalah 265 dan sebannyak 214 data yang bisa dianalisis pada tahap berikutnya. Ini berarti pengembalian kuesioner (response rate), yaitu 
$80,75 \%$. Dari 265 kuesioner yang kembali, semua kuesioner atau sebesar 19,25 \% yang tidak memenuhi persyaratan dan tidak dapat diolah. Sehingga kuesioner yang bisa diolah sejumlah 214 kuesioner atau tingkat pengembalian yang bisa dianalisis senilai 80,75\%.

Berdasarkan Uji Statistik Deskriptif, variabel idealisme $\left(X_{1}\right)$ memiliki skor terndah 26, skor tertinggi 40, skor rata-rata 29,99 dan standardeviasi 3,371. Hal ini membuktikkan adanya perbedaan nilai idealisme berbeda dari nilai rata-rata senilai 3,371 . Nilai rata-rata sebesar 29,99 dengan jumlah 10 pertanyaan pada variabel $X_{1}$ diperoleh rata-rata per pertanyaan sebesar 2,999. Angka ini lebih mendekati 3 yang berarti bahwa sebagian besar responden menjawab setuju (poin 3 ).

Variabel relativisme $\left(X_{2}\right)$ memiliki skor terendah 23 , skor tertinggi 40 , skor rata-rata 30,37 serta standardeviasi 4,220 . Hal ini membuktikkan adanya perbedaan nilai relativisme dengan nilai rata-rata senilai 4,220. Nilai rata-rata senilai 30,37 dengan jumlah 10 pertanyaan pada variabel $X_{2}$ diperoleh rata-rata per pertanyaan sebesar 3,037. Angka ini lebih mendekati yang berarti bahwa sebagian besar responden menjawab setuju (poin 3).

Variabel gender $\left(\mathrm{X}_{3}\right)$ memiliki skor terendah 0 , skor tertinggi 1, skorrata-rata 0,62 dan standar deviasi 0,487 . Hal ini membuktikkan adanya perbedaan nilai gender terhadap nilai rata-rata sebesar 0,487 . Nilai rata-rata sebesar 0,62 dengan jumlah gender sebanyak 2 yang ditandai dengan 0 (laki-laki) dan 1 (perempuan) diperoleh rata-rata per jenis kelamin sebesar 0,31 . Angka ini lebih mendekati 1 yang berarti bahwa sebagian besar responden berjenis kelamin perempuan.

Variabel pengetahuan kode etik akuntan $\left(\mathrm{X}_{4}\right)$ skor terendah 24, skor tertinggi 32, skor rata-rata 28,82 dan standar deviasi 2,864 . Hal ini membuktikkan adanya nilai yang berbeda antara pengetahuan kode etik akuntan terhadap nilai rata-rata sebesar 2,864 . Nilai rata-rata senilai 28,82 dengan jumlah 8 pertanyaan pada variabel $X_{4}$ diperoleh rata-rata per pertanyaan sebesar 3,603. Angka ini lebih mendekati angka 4, maka sebagian besar responden menjawab sangat setuju (poin 4).

Variabel persepsi mahasiswa tentang prilaku tidaketis akuntan $(\mathrm{Y})$ mempunyai skor terendah 6 , skor tertinggi 17 , skor rata-rata 11,18 dan standar deviasi 2,605. Hal inii membuktikan adanya perbedaaan nilai perrsepsi mahasiiswa mengenai perilaku tidak etis akuntan terhadap nilai rata-rata 2,605. Nilai rata-rata sebessar 11,18 dengan jumlah 5 pertanyaan pada variabel $Y$ diperoleh rata-rata per pertanyaan sebesar 2,236. Angka ini lebih mendekati 2 yang berarti bahwa sebagian besar responden menjawab tidak etis (poin 2).

Tabel 1. Hasil Uji Statistik Deskriptif

\begin{tabular}{ccrrrr}
\hline & N & Minimun & Maximum & Mean & Std. Deviation \\
\hline Idealisme $\left(\mathrm{X}_{1}\right)$ & 214 & 26 & 40 & 29.99 & 3.371 \\
Relativisme $\left(\mathrm{X}_{2}\right)$ & 214 & 23 & 40 & 30.37 & 4.220 \\
Gender $\left(\mathrm{X}_{3}\right)$ & 214 & 0 & 1 & .62 & .487 \\
Pengetahuan Kode Etik Akuntan & 214 & 24 & 32 & 28.82 & 2.864 \\
$\left(\mathrm{X}_{4}\right)$ & & & & & \\
Persepsi Mahasiswa (Y) & 214 & 6 & 17 & 11.18 & 2.605 \\
Valid N (listwise) & 214 & & & & \\
\hline
\end{tabular}

Selain uji statistik dekskriptif juga dilakukan uji validitas. Pengujian validitas digunakan menguji keakuratan dari pernyataan atau pertanyaan kuesioner (Ghozali, 2018). Valid atau tidaknya suatu instrumen dalam kuesioner, yaitu jika koefisiennya relasi $r_{\text {hitung }}>$ $r_{\text {tabel }}$ dengan tingkat signifikansi $5 \%$, maaka item pernyataan atau pertannyaan dalam kuesioner dinyattakan valid. Nilai $r_{\text {tabel }}$ pada penelitian ini dengan df 28 adalah 0,374. Berdasarkan hasil uji validitas diperoleh variabel idealisme, relativisme, gender, pengetahuan kode etik akuntan dan persepsi mahasiiswa akuntansi tentang perilaku tidak etis akuntan mempunyai $r_{\text {hitung }}$ (nilai pearson correlation) $>0,374$, ini berarti bahwa pernyataan tersebut valid. 
Uji kualitas data berikutnya, yaitu uji reliabilitas. Indikator metode ini adalah instrument akan reliabel apabila nilai Cronbach's Alpha lebiih dari 0,6 (Ghozali, 2018). Hasiluji reliabilitas bisa dlihat bahwa variabel-variabel membuktikan nilai Cronbach is Allpha lebih tinggi dari 0,60, maka kesimpulannya, yaitu iinstrumen pada penelitian dinyatakan reliabel.

Sesudah uji kualitas data selesai, berikutnya adalah melakukanuji asumssi klasik. Uji asumsi klasiik yang dilakukan awal, yaitu uji normalitas. Ujji nomalitas dilakukn untuk mengetahui normal atau tidaknya suatu populasi data berdistribusi. Kolmogorov Smirnov adalah pada penelitian ini yang emmiliki fungsi unttuk menguji apakah residual terdistribusi secara normal ataupun tidak (Ghozali, 2018). Pada uji ini, peneliti melakukan perbandingan terkait dengan data dari sampel yang dibandingkan dengan distribusi normal pada nilai, serta mean dan standar deviasi yang tidak berbeda. Data akan normal jika nilai residual yang dihasilkan lebih dari nilai signifikan yang ditetapkan $(0,05)$.

Tabel 2. Hasil Uji Normalitas

\begin{tabular}{llr}
\hline & & \\
\hline $\mathrm{N}$ & & Unstandardzed Residual \\
Normal Parameters & Mean & 214 \\
& Std. Deviation & 0,000000 \\
Most Extreme Differences & Absolute & 1,32142847 \\
& Positive & 0,059 \\
& Negative & 0,054 \\
Kolmogorv-Smirnov $Z$ & & $-0,059$ \\
Asymp. Sig. (2-tailed) & & 0,059 \\
& & 0,067 \\
\hline
\end{tabular}

Hasil uji normalitas dilihat dari tabel 2, yaitu nilai signifikan $0,067>0,05$, artinyanilai residual brdistribusi secara normal. Uji asumsi klasik berikutnya yaitu uji heteroskedastisitas. Uji ini memiliki tujuan untuk untuk mengujii suatu model regrresi terjadi ktidaksamaan varian residual suatu pengamatanlain. Jika signifikan dari variabel independen $>0,05$, maka dapat disimpulkan tidak terdaapat heteroskedastistas (Ghozali, 2018). Hasil heteroskedastisitas pada penelitian ini didapat masing variabel bebas tidak signifiikan secara statistiik memengaruhi variabel terikat nilai Absollut Residual. Idealisme memiliki nilaisignifikan 0,839, variabel relativisme memiliki nilai signifikan 0,549, variabel gender memiliki nilai sgnifikan 0,501 , dan variabel pengetahuan kode etik akuntan memiliki nilaisignifikan sebesar 0,194. Seluruh variabel memiliki probabilitas signifikansi $>0,05$, maka kesimpulannya model regresi tidak memillki gejala heteroskedastisitas.

Uji asumsi klasik yang ketiga yaitu uji multikolinearitas. Uji multikoliniaritas bertujuan untukmengukur tingkat asosiasi pengaruh antarvariabel independen dilihat dari besaran koefisien korelasi $(r)$. Model bisa terhindar dari multikolinearitas jika nilai VIF lebih kecil dari 10 dan tolerancelebih besar 0,1, begitu jugapula sebaliknya. Jika nilai VIF semakin besar, maka akan semakin kecil nilai tolerance (Ghozali, 2018). Hasil uji multikolinearitas didapat perhitungan Tolerance menunjukkan variabel idealisme, relativisme, gender dan pengetahuan kode etik akuntan memiliki nilaitolerance bernilai lebih dari 0,10 . Nilai Variance Infation Factor (VIF) setelah dihitung membuktikan variabel idealisme, relativisme, gender dan pengetahuan kode etik akuntan mempunyai VIF yang kurang dari10, maka kesimpulannya, yaitu tidak terjadi Multikolinearitas antarvariabel independent dalam modelregresi.

Analisis regresi berganda dgunakan untuk melihat apakah terdapat pengaruh/tidakknya beberapa variabel bebas trhadap variabel dterikat. Analisis regresi linierberganda yang dilakukan dalam penelitan ini akan menguji tiga variabel bebas, diantaranya idealisme $\left(X_{1}\right)$, relativisme $\left(X_{2}\right)$, dan pengetahuan kode etik akuntan $\left(X_{4}\right)$ serta satu variabel terikat, persepsi mahasiiswa akuntansi mengenai perilaku tiidak etis akuntan $(\mathrm{Y})$.

Uji t berfungsi untuk menguji seberapa jauh 1 variiabel independent secara indvidual bisa menerangkan variabelterikat. Variabel bebas, yaitu idealisme $\left(X_{1}\right)$, relativisme $\left(X_{2}\right)$, dan 
pengetauan kode etik akuntan $\left(X_{1}\right)$, sedangkan variabel terikat yaitu persepsi mahasiswa mengenai periilaku tidak etisakuntan $(Y)$. Alpha $(\alpha)$ yang digunakan sebesar 0,05 . Hasil uji anaisis regresi berganda dan uji-t bisa dilihat pada table 4 berikutt ini.

Hasil analisis regresi linier berganda bisa dlihat dalam tabel 3, yaitu :

\begin{tabular}{|c|c|c|c|c|c|c|}
\hline & \multirow[t]{2}{*}{ Model } & \multicolumn{2}{|c|}{$\begin{array}{l}\text { Unstandardized } \\
\text { Coeficients }\end{array}$} & \multirow{2}{*}{$\begin{array}{c}\begin{array}{c}\text { Standardzed } \\
\text { Coeficients }\end{array} \\
\text { Beta }\end{array}$} & \multirow[t]{2}{*}{$T$} & \multirow[t]{2}{*}{ Sig. } \\
\hline & & $B$ & Std. Error & & & \\
\hline \multirow[t]{4}{*}{1} & (Constant) & 25,354 & 1,548 & & 16,378 & 0,000 \\
\hline & $X_{1}$ & $-0,256$ & 0,029 & $-0,332$ & $-8,975$ & 0,000 \\
\hline & $X_{2}$ & 0,104 & 0,023 & 0,169 & 4,487 & 0,000 \\
\hline & $\mathrm{X}_{4}$ & $-0,276$ & 0,035 & $-0,303$ & $-7,842$ & 0,000 \\
\hline
\end{tabular}

Berdasarkan daritabel 3 di atas, persamaan regresi yang terbentuk, yaitu : $Y=25,354-0,256 X_{1}+0,104 X_{2}-0,276 X_{4}+\varepsilon$

Berdasarkan persamaan regresi yang terbentuk, interpretasinya adalah : Konstanta 25,354 menunjukan jika variabel idealisme $\left(X_{1}\right)$, relativisme $\left(X_{2}\right)$, dan pengetahuan kode etik akuntan $\left(\mathrm{X}_{4}\right)$ bernilai konstan, maka variabel persepsi mahasiswa akunttansi mengenaiperilaku tidaketis akuntan $(Y)$ benilai 25,354.

Idealisme $\left(X_{1}\right)$ memiliki koefisien regresi $-0,256$. Nilai koefisien regresi bernilai negatif. Jika bernilai negatif maka, idealisme $\left(X_{1}\right)$ memilikipengaruh negatif terhadap persepsi mahasiswaakuntansi mengenai perilaku tidaketis akuntan $(Y)$. Dapat digambarkan bahwa setiap kenaikan 1 satuan idealisme $\left(X_{1}\right)$ dapat menurunkan persepsi mahasiswa akuntansi tentang perilakutidak etis akuntan $(Y)$ senilai 0,256 dengan asumsi variabel independent yang lainnya tetap. Nilai signifikan variabel idealisme 0,000 , artinya bahwanilai tersebut lebihkecil dari 0,05 , maka $\mathrm{H}_{1}$ diterima. Jika dihubungkan dengan teori, maka dapat diartikan bahwa semakin tiinggi orientasi idealisme yang dimiliki mahasiswa, maka semakin rendah persepsi penerimaan mahasiswa akuntansi terhadap perilaku tidaketis yang dilakukan akuntan. Kesimpulannya adalah idealism brpengaruh negatif tterhadap persepsi mahasiswa akuntansi mengenaiperilaku tidak etis akuntan.

Relativisme $\left(X_{2}\right)$ memiliki koefisien regresi 0,104 . Nilai koefisien regresi benilai positif. Jika bernilai positif, maka relativisme $\left(X_{2}\right)$ memilikipengaruh positif terhadap persepsi mahasiswaakuntansi mengenai perilakutidak etis akuntan $(Y)$. Dapat digambarkan bahwa setiap kenaikan 1 satuan relativisme $\left(X_{2}\right)$ dapat meningkatkan persepsi mahasiswa akuntansi mengenaiperilaku tidak etis akuntan $(Y)$ bernilai 0,104 dengan asumsi variabel bebas yang lainnya tetap. Nilai signifikansi variabel relativisme adalah 0,000 , artinya artinya bahwa nilai tersebut kurang dari dari 0,05 , maka $\mathrm{H}_{2}$ diterima. Jika dihubungkan dengan teori, maka dapat diartikan bahwa semakin tinggi orientasi relativism yang dimiliki mahasiswa, maka semakin tinggi pula persepsi penerimaan mahasiswa akuntansi terhadap perilaku tidaketis yang dilakukan akuntan. Kesimpulannya adalah relativisme berpengaruh positif terhadap persepsi mahasiswa akuntansi mengenai perilaku tidak etis akuntan.

Pengetahuan kode etik akuntan $\left(X_{4}\right)$ memiliki koefisien regresi $-0,276$. Nilai koefisien regresi bernilai negatif. Jika bernilai negatif, maka pengetahuan kode etik akuntan $\left(X_{4}\right)$ memiliki pengaruhnegatif terhadap persepsi mahasiswa akuntansi mengenai perilaku tidaketis akuntan( $\mathrm{Y})$. Apabila setiap kenaikan 1 satuan pengetahuan kode etik akuntan $\left(\mathrm{X}_{4}\right)$ dapat menurunkan persepsi mahasiswa akuntansi mengenai perilaku tidaketis akuntan ( $Y$ ) bernilai 0,276 dengan asumsi variabel bebas yang lainnya bernilai tetap. Variabel pengetahuan kode etik akuntan mempunyai nilai sgnifikansi bernilai 0,000 . Nilai trsebut kurang dari0,05, maka $\mathrm{H}_{4}$ diterima. Jika dihubungkan dengan teori, maka dapat diartikan bahwa semakin tinggi pengetahuan kode etik akuntan yang dmiliki mahasiswa, maka semakin rendah persepsi penerimaan mahasiswa akuntansi terhadap perilaku tidaketis yang dilakukanakuntan. Kesimpulannya adalah pengetahuan kode etik akuntan berpengaruh negatif terhadap persepsi mahasiswa akuntansi mengenaiperilaku tidaketis akuntan. 
Tabel 4. Hasil Uji Independent-Sampel T-test

Persepsi Mahasiswa Akuntansi Kelompok Laki-laki dan Perempuan

\begin{tabular}{llrrcc}
\hline & Gender & $N$ & Mean & $\begin{array}{c}\text { Perbedaan nilai } \\
\text { mean persepsi } \\
\text { mahasiswa }\end{array}$ & Signifikansi \\
\hline Persepsi & Laki-laki & 82 & 13.30 & 3,44 & 0,000 \\
Mahasiswa $(\mathrm{Y})$ & Perempuan & 132 & 9.86 & 34 \\
\hline
\end{tabular}

Tabel 4 menyajikan hasil analisis IndependentSamples $t$-test yang digunakan untuk menentukan adanya perbedaan persepsimahasiswa akuntansi tentang perilaku tidaketis akuntan kelompok sampel laki-laki serta perempuan. Nilai mean persepsi mahasiswa akuntansi pada kelompok perempuan $(9,86)$ ditemukan lebih rendah 3,44 poin dibandingkan persepsi mahasiswa akuntansi pada kelompok laki-laki $(13,30)$ dan perbedaan ini signifikan pada level signifikansi $\alpha<0,000$. Hal ini mengindikasikan bahwa bahwa kelompok mahasiswa akuntansi laki-laki terbukti lebih memberikan persepsi yang mendukung perilaku tidak etis akuntan dibandingkan dengan kelompok mahasiswa perempuan. Oleh karena itu, $\mathrm{H}_{3}$ pada penelitianini dapat mendukung data empiris. Koefisien determinasi $\left(R^{2}\right)$ adalah uji yang dilakukan untukmengetahui seberapa tiingkat ketepataan yangpaling benar dalam analisaregresi. Koefisien determinasi memberikan petujuk seberapa besar koefisien determinasi $\left(R^{2}\right)$ diantara 0 sampai dengan 1 . Variabelindependen samasekali tidak berpengaruh terhadap variabeldependen koefisien determinasi bernilai nol, sedangkan jika koefisien detrminasi semakin mendekati angka 1, maka kesimpulannya adalah variabel bebas berpengaruh trhadap variabel terikat (Ghozali, 2018).

Tabel 5. Hasil Koefisien Determinasi

\begin{tabular}{rr|r|r|r}
\hline Model & $R$ & $R$ Square & Adjusted R Square & \multicolumn{2}{|c}{$\begin{array}{c}\text { St. Error of the } \\
\text { Estimate }\end{array}$} \\
\hline 1 & $.862^{\mathrm{a}}$ & .743 & .738 & 1.334 \\
\hline
\end{tabular}

Berdasarkan tabel 5, penjelasannya adalah koefisien determinasi0,738. Hal ini mengungkapkan sebesar $73,8 \%$ variabelpersepsi mahasiswa akuntansi tentang perilaku tidaketis akuntan dapat diberikan pengaruh oleh variabel idealisme, relativisme, gender, dan pengetahuan kode etik akuntan, sedangkan $26,2 \%$ diberikan pengaruh oleh faktoryang bukan dari penelitian.

\section{Pengaruh Idealisme terhadap Persepsi Mahasiswa Akuntansi mengenai Perilaku Tidak Etis Akuntan}

Hasil uji regresi linear berganda membuktikan bahwa Idealisme $\left(\mathrm{X}_{1}\right)$ mempunyai koefisien regresi $-0,256$. Nilai koefisien regresi bernilai negatif. Hasil uji t variabel idealisme menghasilkan nilai sgnifikansi 0,000, ini menunjukkan lebihkecil dari 0,05, maka $\mathrm{H}_{1}$ dterima, yaitu idealisme $\left(X_{1}\right)$ memiliki pengaruhnegatif terhadap persepsimahasiswa akuntansi mengenai perilaku tidak etis akuntan $(Y)$.

Idealisme, yaitu suatu tindakan seseorang yang cenderung tidak menerima perilaku tidak etis (Mardawati, 2016). Menurut Nurcahyo dan Ahmar (2012), seseorang yang dapat dipercaya bila dampak yang dimiliki serta keinginan untuk tidak melanggar nilai moral yang berlaku umum disebut dengan idealisme. Seseorang yang memiliki jiwa idealism akan menghindari perilaku yang memberikan dampak buruk atau merugikan oranglain dan seseorang yang idealis ini akan melakukan perilaku jika memiliki konsekuensi tidak baik. Hasil penelitian ini sebanding dengan penelitian Sumiyantini, Sinarwati, dan Atmadja (2017), serta hasil penelitian oleh Damayanthi dan Juliarsa (2016) yang mengungkapkan bahwa idealism berpengaruh secaranegatif tterhadap persepsi mahasiswa akuntansi mengenaii perilaku tidaketis akuntan. 


\section{Pengaruh Relativisme terhadap Persepsi Mahasiswa Akuntansi mengenai Perilaku Tidak Etis Akuntan}

Hasil uji regresi linearberganda membuktikan bahwa Relativisme $\left(X_{2}\right)$ memiliki koefisien regresi 0,104 . Nilai koefisien regresi bernilai positif. Hasil uji t variabel relativisme menghasilkan nilai signifikansi0,000, ini menunjukkan lebih kecil dari0,05, maka $\mathrm{H}_{2}$ diterima, yaitu relativisme $\left(X_{2}\right)$ memiliki pengaruhpositif terhadappersepsi mahasiswa akuntansi mengenai perilaku tidaketis akuntan $(Y)$.

Relativisme menurut pandangan etis adalah peristiwa yang baik dan buruk, benar atau salah bergantung dari seseorang serta budaya di lingkungannya. Menurut Nurcahyo dan Ahmar (2012), relativisme merupakan suatu tindakan yang tidak menerima nilai-nilai moral yang absolut mengenai suatu tindakan. Dzakirin (2013) mengatakan bahwa seseorang yang relativis tidak akan melihat sisi positif dari adanya prinsip etika serta lebih melihat bagaimana kondisi lingkungannya sebelum memberi respon terhadap suatu tindakan dalam pelanggaran etika. Hasil penelitian ini sebanding dengan pnelitian yang dilakukan oleh Yuliani (2019) dan yang dilakukan oleh Damayanthi dan Juliarsa (2016). Hasil penelitian mengungkapkan bahwa relativisme berpengaruh secara positif terhadap persepsi mahasiswa akuntansi mengenai prilaku tidak etis akuntan.

\section{Pengaruh Gender terhadap Persepsi Mahasiswa Akuntansi mengenai Perilaku Tidak Etis Akuntan}

Hasil dasri uji independent sample $t$ test membuktikan nilai mean Gender $\left(\mathrm{X}_{3}\right)$ terhadappersepsi mahasiswa akuntansi mengenai perilaku tidak etis akuntan(Y), gender perempuan sebesar 9,86 dan laki-laki sebesar 13,30. Angka ini mengungkapkan bahwa mean dari kelompok laki-laki lebih tinggi sebesar 3,44 dari pada gender perempuan. Hal ini mengindikasikan bahwa kelompok mahasiswa akuntansi laki-laki terbukti lebih memberikan persepsi yang mendukung perilaku tidak etis akuntan dibandingkan dengan kelompok mahasiswa perempuan. Nilai signifikansi variabel gender adalah 0,000 , berarti nilai ini < 0,05 , maka $\mathrm{H}_{3}$ diterima, yaitu gender $\left(\mathrm{X}_{3}\right)$ memiliki pengaruh terhadap persepsi mahasiswa akuntansi mengenai perilaku tidak etis akuntan $(\mathrm{Y})$.

Menurut Dewi (2016), karakteristik perempuan lebih emosional dan cara berfikirnya lebih menggunakan insting, dimana dalam kondisi ini perempuan cenderung lebih tegas dalam berprilaku etis ataupun menanggapi sesuatu yang ada kaitannya dengan prilaku yang tidak beretika, sedangkan karakteristik laki-laki lebih berfikir secara rasional dan tegas dalam mengambil keputusan. Jadi dapat disimpulkan bahwa laki-laki lebih berfikir sesuai logika dibandingkan dengan perempuan. Hasil pnelitian ini ssesuai dengan penelitian yang diilakukan oleh Akbar (2009), bahwa gender berpngaruh terhdap persepsi mahasiswa mengenai perilaku tidak etis akuntan dimana dapat dijelskan bahwa etika profesiakuntan terdapat perbedaan yang signifikan dimana mahasiswa perempuan lebihbaik menilai perilaku tidak etis daripada mahasiswa laki-laki.

\section{Pengaruh Pengetahuan Kode Etik Akuntan terhadap Persepsi Mahasiswa Akuntansi mengenai Perilaku Tidak Etis Akuntan}

Hasil uji regresi linear berganda menunjukkan bahwa Pengetahuan Kode Etik Akuntan $\left(\mathrm{X}_{4}\right)$ memiliki koefisien regresi $-0,276$. Nilai koefisien regresi bernilai negatif. Hasil uji $t$ variabel pengetahuan kode etik akuntan menghasilkan nilai signifikansi sebesar 0,000 , ini menunjukan lebih kecil dari 0,05 , maka $\mathrm{H}_{4}$ diterima, yaitu pengetahuan kode etik akuntan $\left(\mathrm{X}_{4}\right)$ memiliki pengaruh negatif terhadap persepsi mahasiswa akuntansi mengenai perilaku tidak etis akuntan (Y).

Pengetahuan kode etik akuntan merupakan informasi yang dimilliki oleh akuntan yang digunakan sebagai pedoman dalam bertindak mengenai aturan khusus kode etik akuntan agar dapat terhindar dari tindakan bisa memberikan dampak buruk atau mencoreng citra profesi akuntansi (Rahayu, 2017). Profesi akuntan harus menjunjung tinggi nilai etika dalam menjalankan suatu pekerjaan. Tingkat komitmen moral yang tinggi harus dimiliki oleh seorang yang berprofesi yang terdapat pada bentuk aturan khusus. Aturan khusus adalah 
peraturan untuk dilaksanakan dalam mengemban pekerjaan sebagai prosesi akuntan. Aturan khusus ini disebut dengan kode etik profesi akuntan, diantaranya tanggung jawab profesi, kepentingan publik, integritas, objekivitas, kompetensi dan kehati-hatian, kerahasiaan, perilaku profesional, serta standar etnis (Agoes dan Ardana, 2011).

Hasil penelitian ini sebanding dengan penelitian yang dilakukan oleh Sumiyantini, Sinarwati, dan Atmadja (2017), serta hasil penelitian oleh Mardawati dan Aisyah (2014), yang mengungkapkan bahwa pengetahuan kode etik profesi akuntan berpengaruh secara negatif terhadap persepsi mahasiswa akuntansi mengenai perilaku tidak etis akuntan.

\section{Simpulan Dan Saran}

Berdasarkan hasil analisis data serta pembahasan yang telah dijelaskan, adapunkesimpulannya, yaitu; (1) idealism berpengaruh negatif terhadap persepsi mahasiswa mengenai perilaku tidaketis akuntan; (2) relativisme berpengaruh positif terhadap persepsi mahasiswa mengenai prilaku tidak etisakuntan: (3) kelompok mahasiswa laki-laki terbukti lebih memberikan persepsi yang mendukung perilaku tidaketis akuntan dibndingkan dengan kelompok mahasiswa perempuan; (4) pengetahuan kode etik akuntan berpngaruh negatif terhadap persepsi mahasiswa mengenai perilaku tidak etis akuntan.

Bagi mahasiswa, saran yang diberikan adalah sebagai seorang calon akuntan diharapkan agar memiliki standar etika serta moral yang tidak memihak, agar kepentingan dan kesejahteraan orang lain merupakan hal yang utama dan memberikan keseimbangan baik untuk kepentingan pribadi maupun orang lain. Selain itu agar mahasiswa dapat meningkatkan pengetahuan etika sehingga mahasiswa dapat menilai dengan baik mengenai perilaku etis maupun tidak etis. Penelitian ini menggunakan empat variabel bebas, yaitu Idealisme $\left(\mathrm{X}_{1}\right)$, Relativisme $\left(\mathrm{X}_{2}\right)$, Gender $\left(\mathrm{X}_{3}\right)$, serta Pengetahuan Kode Etik Akuntan $\left(\mathrm{X}_{4}\right)$. Untuk meningkatkan kualitas penelitian, peneliti menyarankan agar peneliti selanjutnya menggunakan variabel yang berbeda seperti kecerdasan emosional, love of money, kecerdasan intelektual, locus of control, religiusitas, dan sebagainya.

\section{Daftar Pustaka}

Afriani, Reti and Darman, Usman. 2017. Pengaruh Orientasi Etis, Pengetahuan Etika dan Locus Of Control Terhadap Persepsi Mahasiswa Akuntansi Atas Perilaku Tidak Etis Akuntan. Undergraduated thesis, Universitas Bengkulu.

Arifin, Zaenal Nur . 2019. Konferensi IAI 2019 di Bali Bahas Profesi Akuntan Harus Beradaptasi Seiring Perkembangan Teknologi.

Damayanthi, Putu Dewi Adi., Gede Juliarsa. 2016. Pengaruh Idealisme, Relativisme, Pengetahuan, Gender Dan Umur Pada Perilaku Tidak Etis Akuntan.

Ghozali, Imam. 2006. Aplikasi Analisis Multivariate dengan Program SPSS. Semarang : Badan Penerbit UNDIP.

Ghozali, Imam. 2018. Aplikasi Analisis Multivariate Dengan Program SPSS. Semarang: Badan Penerbit Universitas Diponegoro.

Ikatan Akuntan Indonesia. 2011. Standar Profesional Akuntan Publik. Jakarta: Salemba Empat.

Mardawati, Revita. Mimin Nur Aisyah. 2014. Pengaruh Orientasi Etis, Gender, Dan Pengetahuan Etika Profesi Terhadap Persepsi Mahasiswa Akuntansi Atas Perilaku Tidak Etis Akuntan.

Novayanti, E. 2017. Pengaruh Orientasi Etis dan Tingkat Pengetahuan Mahasiswa Terhadap Persepsi Mahasiswa Mengenai Perilaku Tidak Etis Akuntansi. Skripsi. Universitas Mahasaraswati.

Nurcahyo, Immanuel Oky., Ahmar, Nurmala. 2012. Idealisme, Relativisme, Dan Kreativitas Akuntan. The Indonesian Accounting Review Volume 2, No. 1, January 2012, pages 73 -90 . 
Nurlan, Andi Besse. 2011. Skripsi : Persepsi Akuntan dan Mahasiswa Jurusan Akuntansi terhadap Kode Etik Ikatan Akuntan Indonesia. Universitas Hasanuddin Makassar.

Rahayu, Septi. 2017. Pengaruh Gender, Pengetahuan Etika Profesi Akuntan, dan Jenis Perguruan Tinggi terhadap Persepsi Mahasiswa Akuntansi Mengenai Creative Accounting. Skripsi : Universitas Negeri Yogyakarta.

Sankaran, S and Bui, T. 2003. "Ethical Attitudes Among Accounting Majors : An Empirical Study". Journal of the American Academy of Business. Vol 3 No 1, pp 71-77.

Sukrisno, Agoes., dan I Cenik Ardana. 2011. Etika Bisnis dan Profesi Tantangan Membangun Manusia Seutuhnya (Edisi Revisi). Jakarta : Salemba Empat.

Sumiyantini, Ni Kadek., Ni Kadek Sinarwati, dan Anantawikrama TunggaAtmadja. 2017. Persepsi Mahasiswa Jurusan Akuntansi Mengenai Idealisme, Relativisme Dan Tingkat Pengetahuan Pada Perilaku Tidak Etis Akuntan (Studi pada Mahasiswa Jurusan Akuntansi Universitas Pendidikan Ganesha).

Yuliani, Kadek Sumi. 2019. Pengaruh Orientasi Etika, Tingkat Pengetahuan Dan Gender Terhadap Persepsi Mahasiswa Mengenai Perilaku Tidak Etis Akuntan. 